\title{
Deviance or acceptable difference: Observance of the Law in Romans 14-15 and Dialogue with Trypho 47
}

\author{
Author: \\ Ronald D. Roberts ${ }^{1}$ \\ Affiliations: \\ ${ }^{1}$ Brite Divinity School, Fort \\ Worth, United States \\ ${ }^{2}$ Department of New \\ Testament Studies, University \\ of Pretoria, South Africa \\ Note: \\ Ronald Roberts is \\ participating in the research \\ project of Prof. Dr Ernest \\ van Eck in the Department \\ of New Testament Studies \\ of the Faculty of Theology \\ at the University of Pretoria, \\ South Africa.
}

Correspondence to:

Ronald Roberts

Email:

ronald.roberts@tcu.edu

Postal address:

3511 Sereno Drive, Laredo,

TX 78046, United States

\section{Dates:}

Received: 06 Jan. 2011

Accepted: 24 Sept. 2011

Published: 10 Feb. 2012

How to cite this article: Roberts, R.D., 2012,

'Deviance or acceptable difference: Observance of the Law in Romans 14-15 and Dialogue with Trypho 47', HTS Teologiese Studies/ Theological Studies 68(1), Art. \#1015, 10 pages. http:// dx.doi.org/10.4102/hts. v68i1.1015
C 2011. The Authors. Licensee: AOSIS OpenJournals. This work is licensed under the Creative Commons Attribution License.
Utilising the symbolic interactionist study of deviance, this article compares the treatment of Law-observant Christ-followers in Romans 14-15 and Justin Martyr's Dialogue with Trypho 47, in order to understand better the declining status of Law-observant Christ-followers in the early Christ-movement. The 'strong' in Romans 14:1-15:13 are likely Christ-followers who do not observe the Law, whilst the 'weak' are likely Christ-followers who do. Although Paul accepts Law-observant Christ-followers, his preference for non-observance decreases the status of those who observe the Law, thereby undermining Paul's vision of a unified, ethnically mixed Church. In Dialogue 47, Justin intensifies the marginalisation of Law-observant Christfollowers by placing them at the very limits of orthodoxy. Dialogue 47 suggests that the campaign for the legitimacy of Law-observant Christ-following was already failing by the middle of the 2nd century, largely because of Paul's own preference for non-observant Christfollowing.

\section{Paul and Law-observance}

Although not by any unanimous consensus, a majority of New Testament scholars currently think that an actual historical situation lies behind Romans 14:1-15:13. ${ }^{1}$ Nevertheless, much

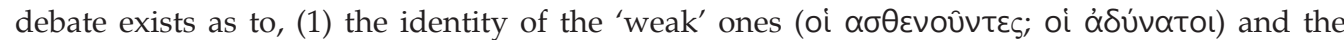

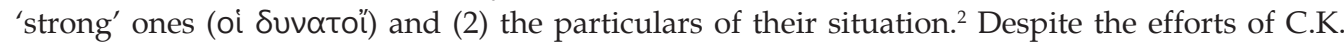
Barrett (1957:256-257) and Ernst Käsemann (1980:367-368), the weak are not likely practicing a syncretistic Judaism. Similarly, Mark Reasoner's (1999:75-87) claim that the weak are Christfollowers observing Pythagorean-style asceticism has found little support. Such theories of syncreticism are attempts to reconcile abstention from meat and wine in Romans 14-15 with the reality that 1st-century Jewish practice (even in the Diaspora) did not require abstention from meat and wine. Nevertheless, several factors strongly suggest that the conflict in Romans 1415 involves Jewish practices, namely, (1) dietary restrictions were often associated with foreign religious practice, especially Judaism, (2) the 'special days' that are mentioned sound similar to Sabbath and Jewish holy days and (3) the evident concern over ritual purity. Both Jews and Gentiles recognised the practices of Sabbath, circumcision and dietary restrictions as primary social identity markers for Jews. ${ }^{3}$ Circumcision proved to be a subject of contention between Paul and certain groups of Jewish Christ-followers, as evidenced in Galatians (Sanders 1983:29). However, circumcision appears to be a non-issue in Romans 14-15.

Concerning the dietary restrictions discussed in Romans 14-15, John M.G. Barclay (1996:291) argues that the abstention from meat and wine resembles Jewish dietary practices. However, the weak are not practicing vegetarianism and teetotalism; instead, they are only refraining from meat and wine whilst eating meals in homes whose residents do not observe the Law. ${ }^{4}$ Previously, James D.G. Dunn (1988b:801-802) has asserted that the reason for such abstinence in Rome was the lack of Jewish slaughterhouses in the city. ${ }^{5}$ Both Dunn (1988b) and Gary Steven Shogren (2000) assume that Claudius's banishment of Jews from Rome practically wiped out the Jewish population in the city. To this end, James C. Walters (1993:60) claims, 'The edict accelerated the

1.See Barclay (1996:287-308); Dunn (1988b:795); Esler (2003:339-356); Watson (1991:203-215); Witherington (2004:325-349).

2.Cf. Jervell (1991:53-64); Karris (1991:65-84); Meeks (1987:290-300); Stowers (1994:321)

3.See Maher (2003:5-10); Walters (1993:84). For examples, see Persius, Satire 5.180-184; Seneca, Epistles 108.17-22. Cf. Hakola (2007:259-276). Yet, 1st-century Judaism was far from monolithic, as Maher (2003:6-10) explains. Nevertheless, Hakola (2007) claims that disagreement and conflict between rival Jewish groups in the Graeco-Roman period tended to revolve around things often held in common, for example, Sabbath, circumcision and diet. Typically, attempts by these Jewish groups to draw distinctions amongst themselves ' $m$ ay be seen as a part of the interplay between an often suppressed sense of sameness and struggles for differentiation' themselves 'may be seen as a part of the interplay between an often suppressed sense of sameness and struggles for differentiation" (Hakola 2007:270). These distinctions are important to Jewish insiders attempting to distinguish themselves from one another however, such distinctions would likely seem rather slight and unimportant in most 1st-century Gentile understandings of the Jews and their customs. Sabbath, circumcision and diet would function as stereotypical Jewish behaviour for most Gentiles and, possibly,

4.See Tobin (2004:207).

5.Cf. Shogren (2000:250-251). 
evolution of the Christ-movement's self-definition as a cult distinct from Judaism. ${ }^{6}$ Walters (1993), himself, admits earlier:

However, attempts to correlate the edict with the content of the Roman letter have failed to assess the effects of the edict with sufficient precision to account for the peculiar argument of Romans. (p. 57)

A few sentences later, Walter (1993:57) comments, 'As indicated earlier, the number of Jews affected by the expulsion is debated.' William L. Lane (1998), for example, contends:

In all probability the decree of expulsion was directed against the members of one or two specific synagogues, who would have been forced to leave the city until there was a guarantee of no further disturbances. (p. 204)

Lane (1998:206) adds that it is likely that those immediately involved in the Chrestus disturbance, particularly missionaries and converts, formed the bulk of those who were expelled. ${ }^{7}$ Accordingly, Barclay (1996:291) determines that speculation concerning the Claudian expulsion and subsequent difficulty in obtaining ritually pure meat in mid-1st-century Rome is unnecessary.

In developing his argument, Barclay (1996) employs Life of Josephus 13-14 and Daniel 1, often cited in reference to Romans 14-15. In Life 13-14, Josephus relates that Jewish priests imprisoned in Rome ate only nuts and fruit. In Daniel 1, Daniel and his three friends persuade their Babylonian supervisor to substitute the king's food and wine for vegetables and water. In both instances, Jews do not avoid food and drink altogether; they avoid food and drink provided by Gentiles. In Life 13-14 and Daniel 1, Jews consume only vegetables and water when ritually pure food was unavailable. When these Jews are finally able to acquire pure food, we should presume that they would cease consuming only vegetables and water. This situation is similar to the one in Esther 14:17 [LXX]. Esther only abstains from food provided by Haman and so we should not assume that she stopped eating altogether. Barclay (1996) argues that the weak in Romans 14-15 restricted their diets to vegetables and water in situations where food prepared only by Gentiles was available.

Abstinence from meat in Romans 14-15 concerns Jewish restrictions on the preparation and consumption of animal flesh. Wine abstinence likely resulted from a concern that non-Jewish libations may have tainted the wine at some point (Barclay 1996:291-292). ${ }^{8}$ Thus, Law-observant Christfollowers would abstain from wine and meat during meals outside non-observant homes, such as during Eucharist and other communal meals in the congregations. When the weak are at home or at another Law-observant home, they would not refrain from meat and wine. The weak likely continued to observe Sabbath and other Jewish holy days. Additionally, Paul's heavy emphasis on eating, with only a brief mention

6.Cf. Walters (1998:176-183).

7.Cf. Suetonius, Claudius 25.4

8.See also Esler (2003:344); Tobin (2004:406-407). of special days, suggests that the central point of contention is the observation of the Law's dietary restrictions (Tobin 2004:405).

At this point, it would be advantageous to make some important terminological distinctions. Firstly, 'Lawobservant' functions as an adjective describing something or someone associated with the practice of all or part of the Jewish Law. 'Non-observant' thus stands as shorthand for 'non-Law-observant'. Secondly, I will avoid the term 'Law-neglect', which Barclay (1996) uses; instead, I prefer the phrase 'non-observance of the Law', or simply 'nonobservance'. This term will avoid the impression that those who do not observe the Law have made a conscious effort to do so. Although some non-observant Christ-followers may refrain consciously from Law-observance, some may do so unconsciously. The converse of 'non-observance' is 'Lawobservance'. Thirdly, I recognise that 'Jewish Christ-follower' and 'Jewish Christianity' are confusing terms. Does 'Jewish Christ-follower' refer to ethnically Jewish members of the Christ-movement? Or does the term refer to any Christfollower who observes all or part of the Law? Thus, I will refer to ethnically Jewish members of the Christ-movement as 'Christ-following Jews'. Similarly, I will avoid the phrase 'Gentile Christ-follower', in favour of 'Christ-following Gentile' as a reference to ethnically non-Jewish Christfollowers. Finally, to focus on the subject at hand, I will therefore avoid the terms 'Jewish Christianity' and 'Gentile Christianity'; instead, I will use the phrases 'Law-observant Christianity' and 'non-observant Christianity'.

With the above in mind, it becomes clear that the weakstrong conflict centres on aspects of Jewish Law (Esler 2003:344). However, Barclay (1996:293, 298) warns against assuming that the weak are Jews and the strong are Gentiles. Many Gentiles in the Graeco-Roman period observed typical Jewish practices, such as Sabbath and dietary restrictions; however, they refrained from full conversion, which involved circumcision for males (Barclay 1996:293, 298). Thus, the weak likely consisted of an ethnically mixed group, of which the majority was Jews (Esler 2003:343). Furthermore, any attempt to equate the strong with only Gentiles is futile. Paul himself, for example, is evidence that some Christ-following Jews had ceased observing much or all of the Law. ${ }^{9}$ Thus, the conflict between the weak and the strong is not entirely about ethnicity. Romans 1-11's concern over Jews and the Law, nevertheless, suggests that ethnicity was only one factor in the conflict. In addition, Paul's talk of the issue of circumcision and Gentiles in Roman 15:8-12, also indicates that ethnicity was a factor in the conflict (Walters 1993:88); however, it was not the only issue.

More than likely, the strong were predominately Gentiles and the weak were mostly Jews. Furthermore, the strong are more likely numerically larger as a group (Segal1986:367). However, the weak are not necessarily a numerically insignificant

9.For Paul's continued self-identification as a Jew, see Freyne (2003:151-152) and Räisänen (1992:125-126). 
portion of the Roman Christ-following community, as some scholars would argue. ${ }^{10}$ As Reasoner (1991:45-58) has noted, 'weak' (inferiores) and 'strong' (potentes) are often indicators of social status within Roman society; thus, the use of these terms in Romans 14-15 suggests the relative status of the two groups within the Roman Christ-following communities. Thus, Reasoner (1991:58-61) considers Paul to be adopting group labels - 'strong' and 'weak' - that the Roman Christfollowers, or at least the strong Christ-followers, were already using. Although I do not accept Reasoner's overall identification of the 'strong' and the 'weak' in Romans 14-15, I do find his insights on the use of these terms as intra-group status indicators very helpful. The designation of one group as 'strong' and the other as 'weak' indicates that, as the higher status group, the strong hold greater social power within the local churches. ${ }^{11}$ Although the label 'strong' may indicate the Law-observant Christ-followers' higher status within the Roman Christ-movement, this label does not necessarily indicate that the Law-observant are the numerically larger group, because the elites, who are the 'strong' within Roman society, likely comprised only $1 \%-5 \%$ of Rome's total population (Stegemann \& Stegemann 1999:77). Nevertheless, in the localised context of the early Roman churches, it seems more likely that the 'strong', non-observant Christ-followers were numerically greater than the 'weak', Law-observant Christ-followers.

That Paul spends 46 verses addressing the situation of the weak and the strong suggests that the conflict, at least in Paul's mind, was a significant disruption in the community. Such a conflict would likely involve two sizeable groups. Nevertheless, I must reiterate that even if the strong are the significantly larger group, the weak are not necessarily numerically insignificant. The majority status of the strong in the Roman Church explains why circumcision is not an issue in Romans 14-15, unlike in Galatians. Christ-following Jews were likely persuading Christ-following Gentiles in Galatia to become full Jewish converts. For male Christ-following Gentiles, conversion to Judaism entailed circumcision (Esler 1998:36-37, 72-75). Yet, in Romans 14-15, the only reference to circumcision is in chapter 15:8, where the circumsicion

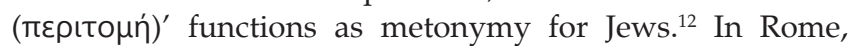
Christ-following Jews attempting to convert Christ-following Gentiles to Judaism are not a major problem. Furthermore, if the dividing line of the two groups is not primarily based on ethnicity, then the absence of circumcision is even more appropriate.

\section{0.cf. Das (2003:66)}

11.Cf. Lee $(2009: 148,150)$. Even if we accept Lee's argument that in Romans 14:1, $\tau$ n̂

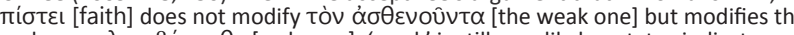
verb $\pi \rho \circ \sigma \lambda \alpha \mu \beta \alpha ́ v \varepsilon \sigma \theta \varepsilon$ [welcome], 'weak' is still very likely a status indicator.

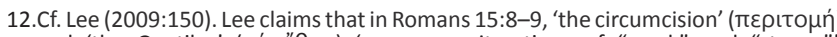
and 'the Gentiles' ( $\tau \dot{\alpha}$ है $\theta \vee \eta)$ 'serve as reiterations of "weak" and "strong". However, in light of the likelihood that the strong and the weak group contained both Jews and Gentiles, it is inappropriate to draw such a distinctive correlation between either the weak and Jewish Christ-followers or the strong and Gentile Christ-followers. In using the ethnic distinctions 'circumcision' and 'Gentile', Paul is not necessarily referring to the respective ethnicities of the strong and weak is not necessarily referring to the respective ethnicities of the strong and weak; instead, it seems more plausible that he is using Christ's service to both Jew and Gentile as an example of how to accept those who are different and the diversity they represent within the Christ-movement. Furthermore, even if Paul does make connection between the weak-strong distinction and the Jew-Gentile distinction, is is meak group and the predominantly Gentile strong group; therefore, 'reiteration' is much too harsh a description of any possible connection between the weak-strong and Jew-Gentile distinctions.
What is important to Paul's discussion of the relations between the weak and strong groups is the concept of 'judging'. A key word in Romans 14 is kpival [to judge], of which some form of the word appears seven times in Romans 14. In addition,

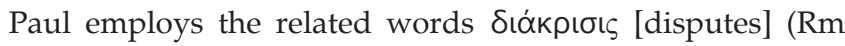

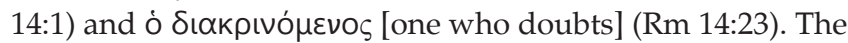
situation in Romans 14-15 is one in which Law-observant Christ-followers are judging the practices of non-observant Christ-followers and vice versa (Barclay 1996:302-303). Thus,

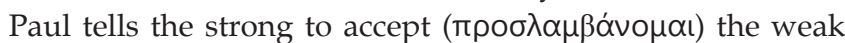
(Rm 14:1). If the immediate context of the conflict is communal meals, then a better translation of $\pi \rho \circ \sigma \lambda \alpha \mu \beta \alpha \dot{v} \sigma \mu \alpha$ w would be 'welcome', which carries connotations of both acceptance and hospitality (Esler 2003:347) ${ }^{13}$ Furthermore, Paul tells the

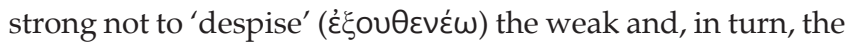
weak are not to 'judge' (кpívw) the strong ( $R m$ 14:3).

However, Paul clearly identifies with one side more than the other, as evidenced by Romans 15:1. ${ }^{14} \mathrm{He}$ does not agree with the weak in their continuance of Jewish dietary restrictions because 'nothing is unclean/impure on its own' (oú $\delta \varepsilon v$


that if someone thinks something impure, then it effectively is impure for that person. For Law-observant Christ-followers to eat unclean food would be tantamount to sinning, at least in their own conscience (to borrow from 1 Cor 8:7). If the strong pressure the weak into eating possibly impure food, the weak person may falter in his or her allegiance to Christ. Christ is a servant (סiókovos) to Jews and Gentiles, to Lawobservant and non-observant Christ-followers (Rm 15:8-9). As Christ has accepted both weak and strong, they should accept one another (Rm 14:13). Yet, Paul speaks mostly to the strong, with whom he identifies. In particular, Paul instructs the strong to bear or endure ( $\beta \alpha \sigma \tau \alpha \dot{\alpha} \zeta \varepsilon เ v)$ the weakness of the weak (Rm 15:1). ${ }^{16}$ Despite his own prohibition against judging, Paul appears to have judged the strong as being more correct in their practices. Even Paul's use or adoption of the terms 'weak' and 'strong' may indicate that he favours one group over the other. Indeed, Paul's favouritism toward the strong, as well as the numeric superiority of this group, places the weak in a 'vulnerable' position. Barclay (1996) explains:

Applying the same principle he had employed in 1 Cor 8-10, Paul warns the strong against putting a stumbling-block in the path of the weak (14.13), which could result in their injury (14.15a) or even destruction (14.15b). Whatever the numerical balance between the weak and strong, it appears that the power relations between the two groups were such that the weak were considerably more vulnerable than the strong. It is implied that the strong, through 'despising' ( $\dot{\xi}$ 'ov $\theta \varepsilon v \varepsilon i ̂ v, 14.3)$ the weak, were liable to pressurize them to act contrary to their own convictions

13.Cf. Bauer et al. (BDAG) (2000:883); Liddle, Scott and Jones (LSJ) (1996:1518-1519). Although LSJ does not list 'welcome' as a possible translation of the middle voice of $\pi \rho \circ \sigma \lambda \alpha \mu \beta \alpha ́ v \omega$, 'admit' into a group, such as the army, is a possible translation.

14.Cf. Barclay (1996:300); Sanders (1983:177-179).

15.Translations of Greek New Testament are mine unless otherwise noted.

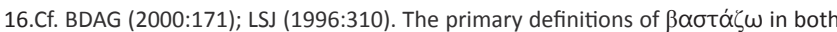
BDAG and LSJ are 'lifting' and 'carrying' objects; however, a more metaphorical usage of the verb is to bear or endure a non-physical burden, which seems most appropriate for Romans 15:1. 
and thus undermine their Christian commitment. Such social disparities are also implicit in the labels 'weak' and 'strong' ... (p. 302)

Likely realising the vulnerability of the weak, Paul spends more time in Romans 14-15 addressing the strong, who need to make accommodations for the weak.

For Paul, the ultimate issue is not whether some food and drink is impure. The primary issue is accepting the Other as he or she is, rather than judging him or her negatively. Instead, both the weak and the strong are to welcome one another because each Christ-follower pleases the Lord. As Barclay (1996:301) explains, 'Paul indicates that the norms of the Christian churches will be decisively different from the defining values of the Jewish community.' If the weak continue in Law-observance and the strong in non-observance, the ethnically mixed Christ-following community should remain relatively intact. Paul's primary goal seems to be the creation and maintenance of fellowship in a diverse Christ-following community (Segal 1986:368). ${ }^{17}$ Thus, in Romans 15:13, he speaks of hope, joy and peace, whilst earlier, in Romans 14:15, he encourages love, rather

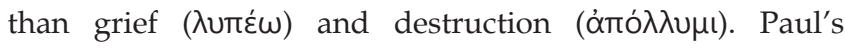

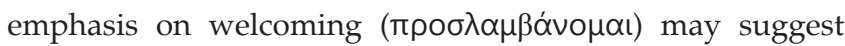
that at least some of the weak and strong have began to meet separately. Nevertheless, Romans 14:1-15:13 gives the impression that if they are meeting separately now, it has not always been this way.

Barclay (1996:303-305) lists three 'conclusions' concerning the 'social effects' of Romans 14:1-15:13. Firstly, 'Paul protects Law-observance and Jewish Christianity.' Secondly, 'Paul allows Law-neglect and a Gentilized Christianity.'18 However, Barclay understates Paul's attitude toward the strong. Paul does not merely allow non-observant Christfollowing - he endorses it as the preferred form. Thirdly, 'Paul effectively undermines the social and cultural integrity of the Law-observant Christians in Rome. ${ }^{19}$ Paul's endorsement of non-observance and his undermining of the integrity of the Law-observant have disastrous results for his overall goal of an ethnically mixed Church (Barclay 1996:308). In a similar vein, Barclay (1996) comments:

But [Paul] himself regards key aspects of the Law as wholly dispensable for Christian believers and, more subtly, his theology introduces into the Roman Christian community a Trojan horse which threatens the integrity of those who sought to live according to the Law. (p. 308)

Paul's endorsement of non-observance does not merely affect church-synagogue relations, but it also affects the relationships within the Church between Law-observant and non-observant Christ-followers. By undermining the integrity of the weak subgroup, Paul effectively undermines

17.Cf. Sanders (1983:207-208).

18.Cf. Sanders (1983:176-177).

19.Cf. Boyarin ( 2004:73)

20.See also Das (2003:76-77). his own vision of a Church that includes both Law-observant and non-observant Christ-followers.

For the sake of clarity, it is necessary to stress that Paul apparently desires a Church in which the Law-observant and non-observant Christ-followers welcome one another as equals and treat one another as partners in the good news of salvation (Lee 2009:150). Paul's policy of mutual acceptance between the Law-observant and the non-observant within local churches was his vision for churches; however, church history indicates that the resulting reality was far different from Paul's desire. Thus, in this article, I am approaching Romans 14-15 with the awareness that Paul's desire and the subsequent historical reality are two different things. Thus, by saying that Paul's unintended favouritism toward the strong undermined his own vision of a unified Church of both Law-observant and non-observant Christ-followers, I am in no way indicating that Paul has a pejorative opinion of Law-observant Christ-followers; instead, it means that Paul's favouritism toward the strong unintentionally sabotages his remarkable (and praiseworthy) goal of a unified Church that accepts diversity.

\section{Competing norms and definitions of deviance}

What is at stake in Romans 14-15 is the definition of normative Christ-following practice in relation to Jewish customs. As such, three options are available. Firstly, normative Christfollowers are those who do not observe the Law and other attendant Jewish customs. Some members of the strong group would likely hold this perspective. Secondly, normative Christ-followers are those who observe the Law. This second definition would be common amongst some members of the weak group. Thirdly, neither Law-observance nor nonobservance determines normative Christ-following practice; therefore, both Law-observance and non-observance occur amongst normative Christ-followers. Some members of both the weak group and strong group, including Paul, hold this opinion. Therefore, the weak and the strong groups are at odds over the limits of acceptable Christ-following behaviour in respect to the observance of Jewish practices.

The interactionist study of deviance focuses on how some groups and individuals in a society or a group are identified and punished as unacceptably abnormal. The interactionist approach examines two sides of deviance. On one hand, interactionists study deviance as a process by which a person becomes deviant and develops his or her 'deviant career' (Becker 1973:24-39). On the other hand, interactionists also analyse how a society or group, in a sense, creates deviance. However, the notion of 'creating' deviance is a bit misleading, for it does not indicate that the society forces a person to become a deviant. What it does mean is that societies and groups engage in a process to identify and control those whom they consider deviant.

Howard S. Becker (1973:147-155) sets out the basics of the deviance process, in which four types of actors participate. 
Firstly, rule-creators are those who carry out a campaign to sway popular opinion that a certain behaviour or characteristic is harmful to the group and/or individuals. The rule-creators will eventually create a rule, law or custom that identifies the activity or characteristic as 'deviance', thereby labelling anyone who participates in the deviance as a 'deviant'. Often, the rule will include corrective measures or punishments controlling the deviant. The second group of actors are rule-enforcers, who are responsible for the identification and punishment of deviance and deviants. An additional goal of rule enforcement is to deter potential deviants from engaging in deviant activities. Rule-creators may also function as rule-enforcers; however, these two groups are often distinct. Becker lumps rule-creators and rule-enforcers into a superordinate group of 'moral entrepreneurs'. The third group of actors, whom Becker does not explicitly mention, is the general public or general group membership. As the moral entrepreneurs successively sway members of the general public to their opinion, those persuaded transfer from the general public to the moral entrepreneurs group. However, the general public also provides the pool for potential deviants. The fourth group of actors are those labelled as 'deviants' by the moral entrepreneurs.

Rules appeal to social values, such as justice or freedom. The problem with values is that they are very generic; therefore, rules function as interpretations and applications of values. Thus, part of the moral enterprise is to sway the public or group majority to believe that their deviance-identifying rules are appropriate applications of common social values (Becker 1973:130-131). The moral enterprise may fail at any point if the social consensus does not consider the rule an appropriate interpretation of the value(s). Additionally, the moral enterprise may fail if the rest of the society or group does not subscribe to the value. In such a case, the value is not a common social value but a value to a particular person or group. The moral enterprise may also fail if the moralenforcers fail to enforce the rule, as well as after a period of success, when popular support for the rule and/or its enforcement dissipates or turns to apathy (Becker 1973:152).

The deviance process becomes complicated when we consider that often 'deviants' will counter by labelling their labellers as 'deviants' (Becker 1973:29). Indeed, as Becker (1973:14) explains, 'Deviance is not a quality that lies in behavior itself, but in the interaction between the person who commits an act and those who respond to it.' Thus, Becker (1973:18) concludes, 'The rules created and maintained by such labeling are not universally agreed to. Instead, they are the object of conflict and disagreement, part of the political process of society.' The moral enterprise of labelling 'deviance' can be a tumultuous 'political process'. Consequently, the identification of deviant behaviour functions as a means of establishing normative behaviour, particularly in conflicts involving what the social actors perceive as mutually exclusive options.

Such a situation is apparently occurring in Romans 14-15, for the identity of the Law-observant Christ-followers is at stake in these chapters. According to Stuart Henry (2009):
Not only can each society have groups of members whose behavior deviates from the cultural or contextual role expectation norms, so too can the behavior of members of these deviant groups be deviant from the norms of the group. (p. 9)

Romans 14-15 appears to be describing a situation of internal deviance within a group already considered deviant by the broader society. Here, the moral entrepreneurs can be divided into three, or possibly four, categories, (1) those who seek to exclude the Law-observant Christ-followers, (2) those who seek to include the Law-observant Christ-followers, (3) those undecided and (4) possibly some Law-observant Christ-followers who want to separate from non-observant Christ-followers.

The broader Christ-following community in Rome likely appealed to similar social values in this conflict. If we assume that Paul represents a moderately 'strong' position (cf. Rm 15:1), the radical strong, who supported the exclusion of the Law-observant, most likely appealed to the value of freedom. The radical weak, who supported the exclusion of the nonobservant, likely appealed to the value of righteousness; that is, obedience to the ordinances of the Law. If we take references to freedom from 'the law of sin and death' and from 'the law' in Romans 8:2-3 as references to the Christfollowers' freedom from the Mosaic Law (Dunn 1988a:418419), we are able to see how Paul himself appeals to the value of freedom for defending the non-observant lifestyle. However, 1 Corinthians 9:19-23 likely reflects Paul's less radical approach toward Law-observance amongst Christfollowers:

Since I am free from all, I enslave myself to all in order that I might gain more people. I became to the Jews as a Jew in order that I might gain Jews. To those under the Law, I became as one under the law, although I myself am not under the law, in order that I might gain those under the law. To those without the Law, I became as one without the Law, not that I am lawless in respect to God but that I am in the law with respect to Christ, in order that I might gain the lawless. I became weak to the weak in order that I might gain the weak. To all I have become all in order that I surely will save some. I do all things on account of the good news in order that I may become a participant in the good news. (1 Cor 9:19-23)

As such, freedom from the Law does not mean that Paul or any other Christ-follower is prohibited from keeping any aspect of the Law; however, it does means that one is free to observe or not to observe the Law. The moderately strong and moderately weak likely appealed to the value of freedom as Paul apparently understood it.

Thus, two hierarchies of values exist. The first is held by everyone, except the radical weak, and places freedom over righteousness. Better yet, it is clear that Paul himself subsumes righteousness under freedom. The sticking point in the conflict is not necessarily different values, but, more importantly, different interpretations of the same values. For Paul, an element of righteousness is freedom from the Law and the equality of all Christ-followers. However, equality is not egalitarianism and thus Paul favours the weak in these 
verses. Although he does not label the weak as 'outsiders', he still recognises difference and subtly indicates that nonobservance is more normative.

Paul seems to be countering an increasingly popular sentiment in the mid-1st-century Roman Christ-movement, specifically the wholesale rejection of Law-observant Christfollowing and Law-observant Christ-followers. Paul seeks to drum up resistance to the radically strong opinion and thwart the radically strong's desire to see Law-observant Christ-followers and their practice excluded from the Roman churches. ${ }^{21}$ Paul himself practices non-observance and, thus, is not a deviant from the strong viewpoint. He is what Erving Goffman would term a 'wise' person; that is, someone who is not a deviant but is familiar with the deviants and accepts them (Goffman 1963:28). Nevertheless, Paul's sympathy in this regard is limited.

\section{Justin Martyr and Law-observant Christ-followers}

The level of influence of Romans 14-15 in the life of the Roman Church, of course, is not available within Paul's letter to Rome. Thus, we must search later writings for clues to the actual effects of Romans 14-15 in the Roman Church. As A. Andrew Das (2003:191) comments, 'Paul's struggle against the Christian Gentiles in Rome, who were already dismissing Judaism and the value of the Mosaic Law, also presaged problems in the future.' Chapter 47 of Justin Martyr's Dialogue, for example, may provide a glimpse at the effects of Romans 14-15 on the Christ-movement in Rome. According to L.W. Barnard (1967:13, 23-24), the purported debate between Justin Martyr and the Jew, Trypho, possibly occurred between 132 CE and 135 CE in Ephesus, with Justin probably writing Dialogue around 160 CE whilst in Rome. ${ }^{22}$ If this is the correct provenance of Dialogue, chapter 47 may have as much to say about the 2nd-century Roman Church as it does about the Asian Church.

In Dialogue 47, Justin answers Trypho's question as to whether Christ-following Jews are saved by Christ and accepted into Christ-following churches. This passage may contain one of the earliest applications of Romans $14-15$ as it contains key words that appear in Romans 14-15. ${ }^{23}$ Of particular importance

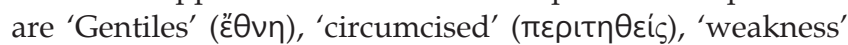

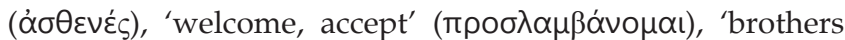

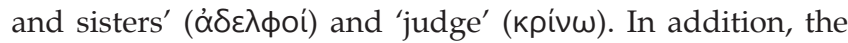

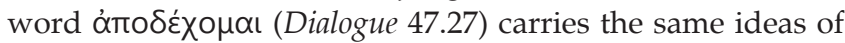

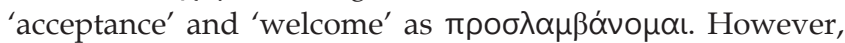
Justin also alludes to 1 Corinthians 8-10 and possibly also to

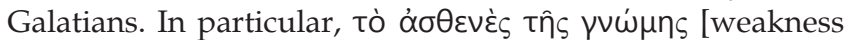
of thinking] in Dialogue 47.15 resembles 'their consciences

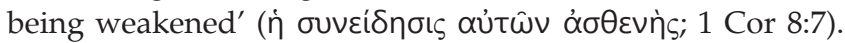
In addition, the concept of Christ-following Jews pressuring Gentiles to undergo circumcision (Dialogue 47.6-7) resembles

21.Cf. Prus and Grills (2003:67).

22.See also Horner (2001:33-63); Parvis and Foster (eds. 2007:xiii); Slusser (2003:xv).

23.Cf. Barnard (1967:62-63). Barnard does not list Dialogue 47 amongst those passages which contain allusions to the Pauline letters.
Galatians more than Romans. Nevertheless, enough similarity exists between Romans 14:1-15:13 and Dialogue 47 to suggest that Justin has Romans, 1 Corinthians and Galatians in mind at this point. What links these three passages and Dialogue 47 is the appearance of words related to weakness. In addition, Romans 14-15, 1 Corinthians 8-11 and Galatians 2:11-21 deal with food restrictions and commensality. Nevertheless, the only specific Jewish observance mentioned in Dialogue 47 is circumcision, which is a non-issue in Romans 14-15. However, as Craig D. Allert (2002:225) has explained, 'In Dial. 12-24 Justin has been referring to circumcision as symbolizing the entire Mosaic Law.' Technically speaking, this rhetorical use of circumcision is metonymy rather than symbolism; nevertheless, this metonymic use of the Law holds true for Dialogue 47 as well.

Justin explains in Dialogue 47 how he thinks the Church should treat Christ-following Jews. He associates Law-observance

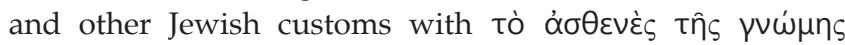
[weakness of thinking]. He has two requirements for Lawobservant Christ-followers in order for him to accept them as genuine Christ-followers. Firstly, they cannot attempt to persuade Christ-following Gentiles to adopt circumcision, Sabbath observance and any other Jewish custom. Secondly,

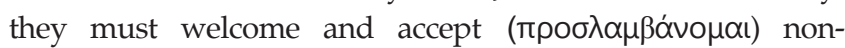
observant Christ-followers and fellowship with them. Justin declares that if Law-observant Christ-followers keep these requirements, he accepts ( $\dot{\pi} \pi \circ \delta \varepsilon \dot{\chi} \chi \mu \alpha \mathrm{l})$ them. Justin prefers non-observance; however, Law-observance does not prevent one from 'being saved'. ${ }^{24}$ As in Romans 14-15, Jewish ritual acts function as cultural identity markers for Justin. For instance, in Romans 15:7, 'the circumcised' functions as a metonym for Jews. Similarly, Justin (e.g. Dialogue 16; 46) considers circumcision to be a characteristic cultural marker of Jews.

I will make a few pertinent observations of Dialogue 47 in relation to my analysis of Romans 14-15. Firstly, Dialogue, as a whole, suggests that dialogue between Christ-followers and Jews outside the Christ-movement was a real possibility. The existence of Dialogue itself attests to this possibility; however, separation of church and synagogue seems to be quite advanced (Remus 1986:67, 73-74). We must also not gloss over the fiercely polemical character of the rhetoric employed by Justin. As such, he demonstrates considerable disdain toward Jews and Jewish customs and he frequently employs derogatory rhetoric and fierce accusations against Jews. Justin is not beyond insults and name-calling. For example, he tells Trypho, 'you are a foolish people and hard-hearted' (Dialogue 123). Furthermore, Justin accuses the Jewish people of murder in relation to the death of the Hebrew prophets and Jesus. ${ }^{25}$ Numerous examples exist within Dialogue in which Justin also appears to usurp Jewish Scripture and ritual by accusing the Jews of misunderstanding Jewish Scripture and consequently defying their own traditions, which leads to further misinterpretation of Scripture. In chapter 55, Justin declares:

24.Translations of Justin's Dialogue are from Roberts and Donaldson's (2001) The Ante-Nicene Fathers, unless otherwise noted.

25.For examples of this, see Justin, Dialogue 93; 95; 102. 
I would not bring forward these proofs, Trypho, by which I am aware those who worship these [idols] and such like are condemned, but such [proofs] as no one could find any objection to. They will appear strange to you, although you read them everyday; so that even from this fact we understand that, because of your wickedness, God has withheld from you the ability to discern the wisdom of His Scripture ... (Dialogue 55:16-22)

According to Justin, not only are the Jews unable to understand Scripture properly, the prophetic gift has transferred from the Jews to Christ-followers (Dialogue 82). In respect to Jewish customs (circumcision, dietary restrictions, etc.), Justin shows disdain for them (Dialogue 14). However, Justin takes over these customs and concepts and gives them new Christ-following significance. ${ }^{26}$ Additionally, he summarily dismisses the Mosaic dietary restrictions. Consequently, Justin either usurps, as Christ-following identity markers, the major Jewish identity markers, or completely dismisses them. Finally, he also excludes from salvation Jews outside the Christ-movement (Dialogue 26; 47; 136); therefore, he considers them to stand under divine condemnation just as the Gentiles outside the Christ-movement (Dialogue 19; $102 ; 136)$.

The result of this fierce polemic is that Jews outside the Christ-movement are enemies for whom Christ-followers should pray. In chapter 96, Justin says:

And in addition to all this we pray for you [Jews], that Christ may have mercy upon you. For he taught us to pray for our enemies also, saying, 'Love your enemies, be kind and merciful, as your heavenly Father is'. (Dialogue 96$)^{27}$

Although Dialogue shows that discussion is possible between a Christ-following Gentile and a Jew who is outside the Christ-movement, such discussion could be filled with conflict, rivalry and venomous accusations.

The second observation concerns Justin's personal opinion regarding the salvation of Law-observant Christ-followers. Justin accepts both Law-observant and non-observant Christfollowers as genuine members of the Christ-movement; however, he admits that some Christ-followers would disagree with him. Toward the beginning of Dialogue 47, Justin begins his conditional acceptance of Law-observant Christ-followers with 'in my opinion, Trypho, such a one will be saved' (Dialogue 47.5). In response, Trypho takes the phrase 'in my opinion' as indication of the existence of a view contrary to Justin's (Dialogue 47.10-11). Subsequently, Justin readily admits that some non-observant Christ-followers do not accept Law-observant Christ-followers as saved.

Thirdly, Justin assumes that the vast majority of Lawobservant Christ-followers are Jewish and demonstrates this assumption in two ways. Justin prohibits Law-observant Christ-followers from persuading Gentiles to undergo circumcision. Furthermore, he refers to Law-observant Christ-

26.See Justin, Dialogue 12 (election); 19; 23-24 (circumcision); 40-41 (passover).

27.Cf. Dialogue 108; Matthew 5:44; Luke 6:27-28, 35. followers as Trypho's kin and siblings (Dialogue 47.19-22). Theodore Stylianopoulos (1975:129) notes that Justin never rules out the possibility of Law-observant Gentile Christfollowers. Nevertheless, Justin seems to assume that nearly all Law-observant Christ-followers are Christ-following Jews. Thus, for Justin, the term 'Law-observant Christ-follower' is effectively synonymous with 'Christ-following Jew'.

Fourthly, Justin assumes that the majority of Christ-followers are Gentiles. He says that he will accept Law-observant Christ-followers who 'chose to live with the Christ-followers and the faithful' (Dialogue 47.18-19). Here Xpıбтıvoi and

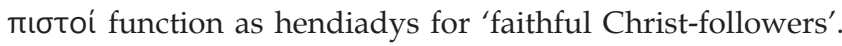
For Justin, 'faithful' is surely a circumlocution for 'orthodox'. Therefore, Justin's stereotypical orthodox Christ-follower is non-observant and Gentile. Daniel Boyarin (2004:37-41) describes Justin as an inventor of Christian heresiology, although he never writes a major heresiological work. Justin is concerned with demarcating certain groups of Christfollowers as heretics, of whom a defining quality is separation from those who practice Justin's form of Christ-following. ${ }^{28}$ Thus, Dialogue 47 seems to be more about defining 'orthodox' and heretical groups. Yet, unlike later Christ-following writers such as Jerome, Justin still considers it possible for Christ-following Jews to be 'orthodox' (Boyarin 2004:26).

Justin's opinions on Law-observant Christ-followers are substantially different from his opinions on the Marcionites. He thinks the 'orthodox' communities should exclude the

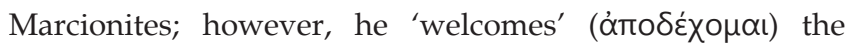
Law-observant Christ-followers into fellowship under two conditions, (1) they must accept other Christ-followers' choice not to observe the Law and (2) they must associate with and participate in the 'non-observant' Christ-following fellowships. Of course, any Christ-followers who reject the validity of non-observance would most certainly disassociate themselves from non-observant Christ-following groups. The underlying principle for Justin is that Law-observant Christ-followers must accept the legitimacy of non-observant Christ-followers; however, Justin does not require nonobservant Christ-followers to accept the legitimacy of Law-observant Christ-followers. Justin indicates that some Christ-followers, who are presumably 'orthodox', do not accept Law-observant Christ-followers as genuine (Dialogue 47.11-12). Failure to accept Law-observant Christ-followers into church fellowship is tantamount to labelling the Lawobservant Christ-follower a 'heretic'.

We likely can assume that Justin has no problem with non-observant Christ-followers pressuring Law-observant Christ-followers to abandon Law-observance. He does not make non-observant Christ-followers' salvation dependent on accepting the Law-observant Christ-followers. Thus, my fifth and final observation is that Justin creates a double standard. Law-observant Christ-followers must accept non-observant Christ-followers, but non-observant Christ-

28.cf. Boyarin (2004:14, 17, 20-21); Justin, Dialogue 35; 82. In chapter 35, Justin labels groups such as the Marcionites and Valentinians 'false prophets', 'false apostles' and blasphemous. In chapter 92 , he says that such heretics are diabolically inspired and stand condemned. 
followers do not have to accept Law-observant Christfollowers. Additionally, Law-observant Christ-followers may not separate into distinct Law-observant churches; instead, they must participate in the churches of the nonobservant. However, non-observant Christ-followers may accept or exclude Law-observant Christ-followers from their communities without any effect on their salvation. Although Justin places Law-observant Christ-followers within the boundaries of 'orthodoxy', he relegates them to a relatively marginal position inside the 'orthodox' church. ${ }^{29}$

\section{Comparing Dialogue 47 with Romans 14:1-15:13}

Justin's approach to Law-observant Christ-followers is quite similar to Paul's approach in Romans. Firstly, both Justin and Paul accept the validity of Law-observant Christ-following, although both consider it to be a weaker form. Secondly, Paul and Justin both want Law-observant Christ-followers to meet in the same congregations as non-observant Christ-followers. Thirdly, both writers apparently know of non-observant Christ-followers who completely reject Law-observant Christ-following and vice versa. Fourthly, Paul and Justin do not require Law-observance for Christ-followers and Law-observance, as noted by Stylianopoulos (1975:128-130), is relatively unimportant for both Paul and Justin. Fifthly, they both prohibit Law-observant Christ-followers from persuading or coercing Gentile Christ-followers to practice the Law. Sixthly, according to both writers, God is the rightful judge of Christ-followers' behaviour.

Nevertheless, some subtle differences exist. Firstly, Justin, unlike Paul, never addresses non-observant Christ-followers' responsibilities toward Law-observant Christ-followers. Secondly, whilst Paul issues a mandate for both the weak and the strong to seek fellowship with one another, Justin does not require non-observant Christ-followers to meet with the Law-observant Christ-followers. Thus, the burden to ensure fellowship between the two types of Christ-followers falls solely upon the Law-observant Christ-followers. Thirdly, Justin sets up a double standard. Law-observant Christfollowers' salvation depends on the acceptance of nonobservant Christ-followers. However, non-observant Christfollowers may be saved regardless of whether they accept Law-observant Christ-followers. Despite Paul's favouritism toward the strong, he does not establish such a double standard. Fourthly, whilst Paul refers to an actual situation involving Law-observant Christ-followers, Justin treats Lawobservant Christ-following rather hypothetically. Fifthly, Paul calls Law-observant Christ-followers 'weak in faith' and simply 'weak', which are certainly pejorative labels. ${ }^{30}$

29.Cf. Boyarin (2004:39-40), who claims that Justin treats Judaism as heresy.

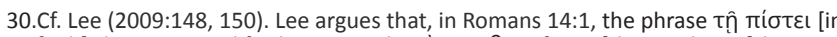
faith] does not modify the participle tòv $\alpha \sigma \theta \varepsilon v 0 u ̂ v \tau \alpha$ [the weak one] because

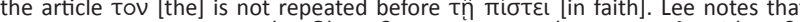

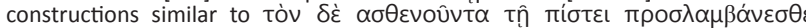
[welcome the weak one in faith] in Romans 14:1, also appear in Romans 4:19-20 and $11: 20$ and these grammatically similar constructions support her translation of the opening clause of Romans 14:1. Although Lee makes a strong argument of the opening clause of Romans 14:1. Although Lee makes a strong argument based on grammar, the syntax of Romans 4:19 actually undermines Lee's reading

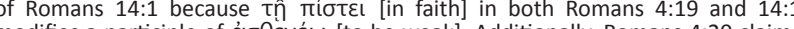
modifies a participle of $\alpha \sigma \theta \varepsilon v \varepsilon \dot{\omega}$ [to be weak]. Additionally, Romans 4:20 claims

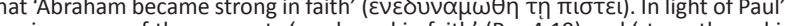
previous uses of the concepts 'weakened in faith' ( $R$ m 4:19) and 'strengthened in faith ( $\operatorname{Rm} 4: 20)$, the translation of the first clause of Romans 14:1 as 'welcome the one weak in faith' is the better translation.
Justin, however, describes them as 'weak-minded', which is a harsher label. Sixthly, Justin takes Paul's favouritism for non-observant Christ-following to another level by setting Law-observance on the very margins of 'orthodoxy'. The only thing keeping the Law-observant from being heretics is their willingness to accept and meet with non-observant Christ-followers. Seventhly, Justin addresses the issue of Christ-following Jews who have renounced Christ. These former Christ-followers will face severe punishment at God's final judgement. Upon renouncing Christ, the former Christ-followers fall into the same category as heretics who misrepresent Christ and deserve condemnation at the eschatological judgement. Nowhere in Romans, nor anywhere else, does Paul explicitly address a situation in which Jewish Christ-followers renounce their Christfollowing identity.

\section{Justin and Law-observant Christ- followers in the 2nd-century}

We must be mindful that the educated Justin does not speak for all Christ-followers of his time. He possibly even represents a minority opinion. Although Justin's opinions may not always be characteristic of the 2nd-century Christ-movement (Stylianopoulos 1975:129), we can still piece together from Dialogue 47 some insights into the state of 2nd-century Jewish Christ-followers and Christ-following Law-observance, particularly in Rome. Firstly, despite Paul's desire to include Law-observant Christ-followers in the Church, Lawobservance was becoming increasingly marginal in the 2ndcentury Church. At best, the Law-observant Christ-followers would be on the acceptable fringe of the 'orthodox'. At worst, either voluntarily or involuntarily (or a bit of both), they were outside the bounds of 'orthodoxy'. Thus, some (or even most) of the 'orthodox' would consider the Law-observant Christ-followers to be heretics. Secondly, the variety of opinions, of which Justin admits the existence, coincides with Peter Lampe's (2003:359-412) 'fractionation' of the early Roman Church. Thirdly, Justin's strong insistence that Lawobservant Christ-followers must not segregate into separate communities betrays the likely reality that a significant portion of Jewish Christ-followers disassociated themselves from other Christ-following congregations. Fourthly, the existence of those who do not accept the validity of Lawobservance suggests that many Law-observant churches involuntarily meet separately. Nevertheless, Justin, and likely many others, places the blame for such segregation firmly on the Law-observant Christ-followers; thus, Justin and others create an impossible double standard for Law-observant Christ-followers. On the one hand, the Law-observant Christfollowers were to meet with non-observant Christ-followers. On the other hand, it was impossible for them to do so. Under Justin's guidelines, the only way for them to be saved in such a situation was to stop observing the Law. Nevertheless, due to Jewish concern for ritual purity at table, they were also likely to form separate Law-observant congregations entirely of their own choice. Fifthly, both Romans 14-15 and Dialogue 47 indicate that non-observant Christ-followers were in a better position to pressure Law-observant Christ-followers 
into non-observance, as compared to the Law-observant Christ-followers' ability to coerce the non-observant Christfollowers. Sixthly, Paul's vision of a unified Church of both Jews and Gentiles was becoming increasingly unlikely as Law-observance became increasingly marginalised. Seventhly, if Justin represents a minority opinion on the issue, then Law-observant Christ-following was far more marginalised than Justin wants to admit. Thus, Dialogue 47 may be an attempt to revive Paul's nearly abandoned vision of a unified Jewish and Gentile church. Justin's conception of a unified church is quite likely wishful thinking more than it is a reality. ${ }^{31}$

Justin envisions a Church that is both Jewish and Gentile. However, the marginal status to which Justin relegates Lawobservant Christ-followers undermines such a vision..$^{32}$ The foundation for such a paradoxical vision is evident in Romans 14-15. Here Paul, himself, weakens his own vision of a church that includes both Law-observant and non-observant, when he paradoxically judges Law-observant Christ-followers to be weak and their practices irrelevant. With Justin, we see the paradoxes in Paul's own arguments play out to their logical conclusions. Although Paul forbids the Romans to judge one another concerning Law-observance, he clearly favours nonobservance, which is strong enough to 'endure' ( $\beta \alpha \sigma \tau \alpha \dot{\zeta} \zeta \varepsilon \mathrm{lv})$ the weak (Rm 15:1). Thus, Paul attempts to establish in Rome his ideology of an ethnically mixed Church of both Jew and Gentile, a community in which Law-observance and nonobservance would be acceptable (Walters 1993:91-92). ${ }^{33}$ As Justin demonstrates, such a vision is still unrealised roughly a century later. Yet the seeds of failure are sown by Paul himself. Paul subtly, and likely unintentionally, places weak, Law-observant Christ-followers in an inferior position to the strong non-observant Christ-followers.

\section{Law-observance and deviant Christ- following}

By the middle of the 2nd century, a portion, if not the majority, of Christ-followers considered Law-observance to be unacceptable practice in Christ-following communities. Thus, the non-observant Christ-followers, at some point, had become moral entrepreneurs engaging in a campaign to prohibit Law-observance amongst Christ-followers. They had interpreted the values of freedom and salvation by grace to indicate that Law-observance was unnecessary and unacceptable. In many sectors of the Christ-movement, non-observant Christ-followers were identifying 'Lawobservance' as deviance; thus, they were identifying Lawobservant Christ-followers as 'deviants' and were excluding

31.Cf. Allert (2002:58). Allert treats Justin's Dialogue as a more reliably accurate picture of Jew-Gentile relations in the 2nd-century Church. Here he comments, Justin is a strong testimony to a variegated Jewish-Christian community in his time, and he hints that successful missionary activity was occurring between Christians and Jews, and between Jewish Christians and Gentile Christians.'

32.Whether the intended audience of Dialogue is Christ-followers, Jews outside the Christ-movement, or participants in any of the Graeco-Roman cults makes little difference at this point. If the intended audience is Christ-followers, the marginalising effects of Dialogue 47 are certainly heightened. For more on the intended audience of Dialogue, see Cosgrove (1982:209-232); Stylianopoulos
(1975:169-195).

33.Cf. Esler (2003:350); Sanders (1983:172) them from some 'orthodox' communities. Justin attempts to promote an approach similar to the one taken by Paul nearly 100 years earlier: Law-observant Christ-followers are 'different' but not 'deviant'. His criticism of Law-observant Christ-followers pushes them to the edges of what is acceptable, and his stereotype of a Christ-follower centres on non-observance. For some, this deviation from the stereotype was enough to place Law-observant Christ-followers outside the 'orthodox' section of the Christ-movement; however, for Justin, they were only at the margins of the normative community.

At the dawning of Christ-follower heresiology, Justin places Law-observant Christ-followers, predominantly consisting of Christ-following Jews, at the margins of orthodoxy. Despite Paul's own desire for an ethnically mixed Church, his own partiality toward Law-observance undermines this desire and sets a course for the future marginalisation of Law-observant Christ-followers. As a moral entrepreneur, Paul argues for an ideology of a mixed Christ-following community of Lawobservant and non-observant Christ-followers; however, an element of that ideology is a favouritism that undermines the integrity of the culture of Law-observant Christ-followers, particularly Law-observant Christ-following Jews. Justin extends Paul's ideology and marginalises Law-observant Christ-followers to a second-class position. Paul's moral campaign to include Law-observant Christ-followers in the Christ-movement and to prohibit the exclusion of Lawobservant Christ-followers seems unsuccessful by the 2nd century. Paul's own favouritism seems to be a factor in this lack of success of his own moral campaign and the ultimate success of the opposing perspective to label Law-observant Christ-following as a 'deviance' and, accordingly, Lawobservant Christ-followers as 'deviants'. From a macro-social perspective, the so-called orthodox section of the Christmovement begins increasingly to lump the Law-observant Christ-followers with Jews outside the Christ-movement, Gentiles outside the Christ-movement, Gnostic Christfollowers, and other 'heretical' Christ-following groups, all of whom the self-proclaimed 'orthodox' Christ-followers had already labelled as 'outsiders' and deviants in respect to the 'orthodox' conception of the God-ordained moral order of the cosmos.

\section{Acknowledgements Competing interests}

The author declares that he has no financial or personal relationship(s) which may have inappropriately influenced him in writing this article.

\section{References}

Allert, C.D., 2002, Revelation, truth, canon and interpretation: Studies in Justin Martyr's, Dialogue with Trypho, Supplements to Vigiliae Christianae 64, Brill, Leiden.

Barclay, J.M.G., 1996, "'Do we undermine the Law?": A study of Romans 14.1-15.6', in J.D.G. Dunn (ed.), Paul and the Mosaic Law, Wissenschaftliche Untersuchungen zum Neuen Testament 89, pp. 287-308, Mohr Siebeck, Tübingen. 
Barnard, L.W., 1967, Justin Martyr: His life and thought, Cambridge University Press, Cambridge.

Barrett, C.K., 1957, A commentary on the Epistle to the Romans, ed. H. Chadwick, Harper and Row, New York. (Harper's New Testament commentaries.)

Bauer, W., Arndt, W.F., Gingrich, F.W. \& Danker, F.W. (eds.) 2000, A Greek-English lexicon of the New Testament and other early Christian literature, 3rd edn., University of Chicago Press, Chicago.

Becker, H.S., 1973, Outsiders: Studies in the sociology of deviance, Free Press, New York.

Boyarin, D., 2004, Border lines: The partition of Judaeo-Christianity divinations: Rereading late ancient religion, University of Pennsylvania Press, Philadelphia.

Cosgrove, C.H., 1982, 'Justin Martyr and the emerging Christian canon: Observations on the purpose and destination of the Dialogue with Trypho', Vigiliae Christianae
$36,209-232$. http://dx.doi.org/10.1163/157007282X00116, http://dx.doi. $36, \quad 209-232 . \quad$ http $/ / C$
org/10.2307/1583381

Das, A.A., 2003, Paul and the Jews, Hendrickson, Peabody. (Library of Pauline Studies.)

Dunn, J.D.G., 1988a, Romans 1-8, Nelson Reference and Electronic, Nashville. (Word biblical commentary 38A.)

Dunn, J.D.G., 1988b, Romans 9-16, Nelson Reference and Electronic, Nashville (Word biblical commentary 38B.)

Esler, P.F., 1998, Galatians, Routledge, London. (New Testament readings.)

Esler, P.F., 2003, Conflict and identity in Romans: The social setting of Paul's letter Fortress, Minneapolis.

Freyne, S., 2003, 'The Jesus-Paul debate revisited and re-imaging Christian origins', in Kieran J. \& O'Mahony (ed.), Christian origins: Worship, belief and society: The Milltown Institute and the Irish Biblical Association Millennium Conference, The Milltown Institute and the Irish Biblical Association Millennium Conference,
Journal for the Study of the New Testament suppl. ser. 241, pp. 143-163, Sheffield Academic, Sheffield.

Goffman, E., 1963, Stigma: Notes on the management of spoiled identity, PrenticeHall, Englewood Cliffs.

Hakola, R., 2007, 'Social identities and group phenomena in Second Temple Judaism', in P. Luomanen, I. Pyysiäinen \& R. Uro (eds.), Explaining Christian origins and early Judaism: Contributions from cognitive and social science, Biblical interpretation ser. 89 , pp. 259-276, Brill, Leiden. http://dx.doi.org/10.1163/ interpretation ser. $89, \mathrm{pp}$.
ej.9789004163294.i-328.77

Henry, S., 2009, Social deviance, Polity, Cambridge. (Polity short introductions.)

Horner, T.J., 2001, 'Listening to Trypho': Justin Martyr's Dialogue Reconsidered Peeters, Leuven. (Contributions to biblical exegesis and theology 28. .)

Jervell, J., 1991, 'The Letter to Jerusalem', in K.P. Donfried (ed.), The Romans Debate, rev. edn., pp. 53-64, Hendrickson, Peabody.

Justin Martyr, 2001, 'Dialogue of Justin, philosopher and martyr with Trypho, a Jew', in A. Roberts \& J. Donaldson (eds.), The Ante-Nicene Fathers, vol. 1, pp. 1885-1887, reprinted in Christians Classics Ethereal Library, CD-ROM, v. 4, Calvin College, Grand Rapids.

Karris, R.J., 1991, 'Romans 14:1-15:13 and the occasion of Romans', in K.P. Donfried (ed.) The Romans debate, rev. edn., pp. 65-84, Hendrickson, Peabody.

Käsemann, E., 1980, Commentary on Romans, transl. G.W. Bromiley, Eerdmans, Grand Rapids.

Lampe, P., 2003, From Paul to Valentinus: Christians at Rome in the first two centuries, ed. M.D. Johnson, transl. M. Steinhauser, Fortress, Minneapolis.

Lane, W.L., 1998, 'Social perspectives on Roman Christianity during the formative years from Nero to Nerva: Romans, Hebrews, 1 Clement', in K.P. Donfried \& P. Richardson (eds.), Judaism and Christianity in first-century Rome, pp. 196-244, Eerdmans, Grand Rapids.
Lee, J-W., 2009, 'Paul and ethnic difference in Romans', in R.C. Bailey, T-S. Benny Liew \& F.F. Segovia (eds.) They were all together in one place? Toward minority biblical criticism, Semeia Studies 57, pp. 141-157, Society of Biblical Literature, Atlanta.

Liddell, H.G., Scott, R. \& Jones, H.S., with McKenzie, R., 1996, A Greek-English Lexicon, 9th supplemented edn., Clarendon, Oxford.

Maher, M., 2003, 'Knowing the tree by its roots: Jewish context of the early Christian Movement', in K.J. O'Mahony (ed.), Christian origins: Worship, belief and society: The Milltown Institute and the Irish Biblical Association Millennium Conference, Journal for the Study of the New Testament suppl. ser. 241, pp. 1-28, Sheffield Academic, Sheffield.

Meeks, W.A., 1987, 'Judgment and the brother: Romans 14:1-15:13', in G.F. Hawthorne \& O. Betz (eds.), Tradition and interpretation in the New Testament: Essays in honor of E. Earle Ellis for his $60^{\text {th }}$ birthday, pp. 290-300, Eerdmans, Grand Rapids.

Parvis, S. \& Foster, P. (eds.), 2007, Justin Martyr and his worlds, Fortress, Minneapolis.

Prus, R. \& Grills, S., 2003, The deviant mystique: Involvements, realities, and regulation, Praeger, Westport.

Räisänen, H., 1992, 'Galatians 2.16 and Paul's break with Judaism', in Räisänen, H. (ed.), Jesus, Paul and Torah: Collected essays, Journal for the Study of the New Testament suppl. ser. 43, transl. D.E. Orton, pp. 112-126, JSOT, Sheffield.

Reasoner, M., 1999, The strong and the weak: Romans 14.1-15.13 in Context Cambridge University Press, Cambridge. (Society for New Testament Studies monograph ser. 103.

Remus, H., 1986, 'Justin Martyr's argument with Judaism', in S.G. Wilson (ed.) Separation and anti Judaism in early Christianity, vol. 2, Separation and Polemic, Studies in Christianity and Judaism, pp. 59-80, Canadian Corporation for Studies in Religion and Wilfrid Lauier University Press, Waterloo.

Sanders, E.P., 1983, Paul, the Law, and the Jewish people, Fortress, Philadelphia.

Segal, A.F., 1986, 'Romans 7 and Jewish dietary Law', Studies in Religion 15, 361-374.

Shogren, G.S., 2000, '"Is the Kingdom of God about eating and drinking or isn't it?" (Romans 14:17)', Novum Testamentum 42, 238-256. http://dx.doi. org/10.1163/156853600506645

Slusser, M., 2003, 'Introduction to the first edition of Justin Martyr', in M. Slusser \& T.P. Halton (eds.), Dialogue with Trypho, Selections of the Fathers of the Church 3, transl. T.B. Falls, rev. edn., pp. xv-xvi, Catholic University of America Press, Washington, DC.

Stegemann, E.W. \& Stegemann, W., 1999, The Jesus movement: A social history of its first century, transl. O.C. Dean, Jr, Fortress, Minneapolis.

Stowers, S.K., 1994, A rereading of Romans: Justice, Jews, and Gentiles, Yale University Press, New Haven.

Stylianopoulos, T., 1975, Justin Martyr and the Mosaic Law, Society of Biblical Literature and Scholars, Missoula. (SBL dissertation ser. 20.)

Tobin, T.H., 2004, Paul's rhetoric in its contexts: The argument of Romans, Hendrickson, Peabody.

Walters, J.C., 1993, Ethnic issues in Paul's Letter to the Romans: Changing selfdefinitions in earliest Roman Christianity, Trinity Press International, Valley Forge.

Walters, J.C., 1998, 'Romans, Jews, and Christians: The impact of the Romans on Jewish/Christian relations in first-century Rome', in K.P. Donfried \& P. Richardson Judaism and Christianity in first century Rome, pp. 175-195, Eerdmans, Grand Rapids.

Watson, F., 1991, 'The two Roman congregations: Romans 14:1-15:13', in K.P. Donfried (ed.), The Romans debate, rev. edn., pp. 203-215, Hendrickson, Peabody.

Witherington, B., III, with D. Hyatt, 2004, Paul's Letter to the Romans: A sociorhetorical commentary, Eerdmans, Grand Rapids. 